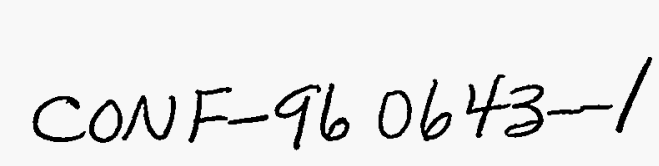

R. L. Klueh ${ }^{1}$ and D. J. Alexander ${ }^{1}$

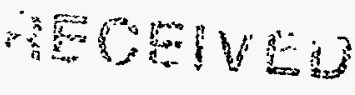

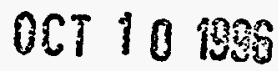

OSTI

\title{
TENSILE AND CHARPY IMPACT PROPERTIES OF IRRADIATED REDUCED- ACTIVATION FERRITIC STEELS
}

REFERENCE: Klueh, R. L. and Alexander, D. J., "Tensile and Charpy Impact Properties of Irradiated Reduced-Activation Ferritic Steels," Effects of Radiation on Materials: 18th International Symposium, ASTM STP 1325, R. K. Nanstad, M. L. Hamilton, F.A. Garner, and A.S. Kumar, Eds., American Society for Testing and Materials, 1997.

ABSTRACT: Tensile tests were conducted on eight reduced-activation Cr-W steels after irradiation to 15-17 and 26-29 dpa, and Charpy impact tests were conducted on the steels irradiated to $26-29 \mathrm{dpa}$. Irradiation was in the Fast Flux Test Facility at $365^{\circ} \mathrm{C}$ on steels containing $2.25-12 \% \mathrm{Cr}$, varying amounts of $\mathrm{W}, \mathrm{V}$, and $\mathrm{Ta}$, and $0.1 \% \mathrm{C}$. Previously, tensile specimens were irradiated to 6-8 dpa and Charpy specimens to 6-8,15-17, and 20$24 \mathrm{dpa}$. Tensile and Charpy specimens were also thermally aged to $20000 \mathrm{~h}$ at $365^{\circ} \mathrm{C}$. Thermal aging had little effect on the tensile behavior or the ductile-brittle transition temperature (DBTT), but several steels showed a slight increase in the upper-shelf energy (USE). After $\approx 7 \mathrm{dpa}$, the strength of the steels increased (hardened) and then remained relatively unchanged through $26-29$ dpa (i.e., the strength saturated with fluence). Postirradiation Charpy impact tests after 26-29 dpa showed that the loss of impact toughness, as measured by an increase in DBTT and a decrease in the USE, remained relatively unchanged from the values after 20-24 dpa, which had been relatively unchanged from the earlier irradiations. As before, the two $9 \mathrm{Cr}$ steels had the most irradiation resistance.

KEYWORDS: ferritic steels, reduced-activation, tensile properties, impact properties

Alloy development programs are in progress in Japan, the European Union, the United States, and Russia to develop reduced-activation or fast induced-radioactivity decay (FIRD) ferritic steels for fusion power plant applications [1]. Components of a plant constructed from such steels could be more readily disposed of or recycled after service than if they were made from conventional alloys [2]. A FIRD or reduced-

DISTRIBUTION OF THS DOCUMENT IS UNLIATEED

${ }^{1}$ Research staff, Metals and Ceramics Division Oak Ridge National Laboratory, Oak Ridge, TN 37831-6376

-The submitted manuscript has been authored by a contractor of the U.S. Government under contract No. DE-AC05-960R22464. Accordingly, the U.S. Government retains a nonexclusive, royalty-free license to publish or reproduce the published form of this contribution, or allow others to do so, for U.S. 


\section{DISCLAIMER}

Portions of this document may be illegible in electronic image products. Images are produced from the best available original document. 
activation alloy cannot contain niobium and molybdenum [2], important constituents in conventional Cr-Mo steels of interest for fusion, which in the U.S. fusion program included $21 / 4 \mathrm{Cr}-1 \mathrm{Mo}, 9 \mathrm{Cr}-1 \mathrm{MoVNb}$, and $12 \mathrm{Cr}-1 \mathrm{MoVW}$.

The eight experimental steels discussed in this paper were based on compositions of conventional Cr-Mo steels with molybdenum replaced by tungsten and niobium replaced by tantalum [1]. Nominal compositions are given in Table 1, along with the designation for each steel. As a generic designation, the new class of steels will be referred to as $\mathrm{Cr}$ $\mathrm{W}$ steels, chromium and tungsten being the primary constituents after iron. (An exception to this is the $21 / 4 \mathrm{CrV}$ steel, which contains no tungsten.) This designation follows the procedure used for the Cr-Mo steels, after which these steels are patterned, even though both types of steel may contain other alloying elements (i.e., V, Ta, etc.).

TABLE 1--Nominal compositions for reduced-activation steels

\begin{tabular}{lccccc}
\hline Alloy & \multicolumn{5}{c}{ Nominal Chemical Composition (wt \%) } \\
\cline { 2 - 6 } & $\mathrm{Cr}$ & $\mathrm{W}$ & $\mathrm{V}$ & $\mathrm{Ta}$ & $\mathrm{C}$ \\
$2.25 \mathrm{CrV}$ & 2.25 & & 0.25 & & 0.1 \\
$2.25 \mathrm{Cr}-1 \mathrm{WV}$ & 2.25 & 1.0 & 0.25 & & 0.1 \\
$2.25 \mathrm{Cr}-2 \mathrm{~W}$ & 2.25 & 2.0 & & & 0.1 \\
$2.25 \mathrm{Cr}-2 \mathrm{WV}$ & 2.25 & 2.0 & 0.25 & & 0.1 \\
5Cr-2WV & 5.0 & 2.0 & 0.25 & & 0.1 \\
9Cr-2WV & 9.0 & 2.0 & 0.25 & & 0.1 \\
9Cr-2WVTa & 9.0 & 2.0 & 0.25 & 0.12 & 0.1 \\
12Cr-2WV & 12.0 & 2.0 & 0.25 & & 0.1
\end{tabular}

Balance iron.

Information on microstructure [ $\underline{3}$ ], tempering and tensile behavior [4], and Charpy impact behavior [ $[\underline{]}$ of the eight FIRD steels in the unirradiated condition has been reported. Results were also published on the tensile properties after irradiation to 6-8 dpa [] ] and the Charpy properties after irradiation to 6-8 [] ], 15-17 [7], and 23-24 dpa [] at $365^{\circ} \mathrm{C}$ in the Fast Flux Test Facility (FFTF). Charpy specimens have now been irradiated to $26-29 \mathrm{dpa}$ and tensile specimens have been irradiated to $15-17$ and $26-29 \mathrm{dpa}$ at $365^{\circ} \mathrm{C}$ in the FFTF. In this paper, these data will be presented and combined with the previous data to analyze the effect of irradiation on the properties. Observations on impact behavior are extremely useful because neutron irradiation causes an increase in the ductilebrittle transition temperature (DBTT) and a decrease in upper-shelf energy (USE) of ferritic steels; those effects generally reflect a degradation in fracture toughness. Developing steels with minimal changes in these parameters is crucial if ferritic steels are to be useful structural materials for fusion. 


\section{EXPERIMENTAL PROCEDURE}

Eight electroslag-remelted heats of FIRD steels with the nominal compositions and alloy designations given in Table 1 were prepared by Combustion Engineering, Inc. These steels were used in previous studies, and melt compositions have been published [ 3 ]. In addition to nominal compositions of $\mathrm{Cr}, \mathrm{W}, \mathrm{V}, \mathrm{C}$, and $\mathrm{Ta}$, elements normally found in steels, such as $\mathrm{Mn}, \mathrm{Si}$, etc., were adjusted to levels typical of commercial practice.

The steels were normalized and tempered prior to aging and irradiation. The $21 / 4 \mathrm{Cr}-2 \mathrm{~W}$ steel was austenitized $1 \mathrm{~h}$ at $900^{\circ} \mathrm{C}$ and air cooled. The other seven heats contained vanadium and were austenitized $1 \mathrm{~h}$ at $1050^{\circ} \mathrm{C}$ and air cooled; the higher normalizing temperature assured that any vanadium carbide dissolved during austenitization. The $21 / 4 \mathrm{CrV}, 21 / 4 \mathrm{Cr}-1 \mathrm{WV}$, and $21 / 4 \mathrm{Cr}-2 \mathrm{~W}$ steels were tempered $1 \mathrm{~h}$ at $700^{\circ} \mathrm{C}$; the other five heats were tempered $1 \mathrm{~h}$ at $750^{\circ} \mathrm{C}$.

Tensile specimens were machined from $0.76-\mathrm{mm}$ sheet. In this case, heat treatments were made on the machined specimens and were carried out in a helium atmosphere. Rapid cooling was achieved by pulling the specimens from the tube furnace and cooling in flowing helium. The tensile specimens were $25.4 \mathrm{~mm}$ long and had a reduced gage section of $7.62 \mathrm{~mm}$ long by $1.52 \mathrm{~mm}$ wide by $0.76 \mathrm{~mm}$ thick. Tensile tests were made at $365^{\circ} \mathrm{C}$ in vacuum on a $120-\mathrm{kN}$ Instron universal machine at a nominal strain rate of $\approx 1 \times 10^{-3} / \mathrm{s}$.

One-third size Charpy specimens measuring $3.3 \times 3.3 \times 25.4 \mathrm{~mm}$ with a $0.51-\mathrm{mm}$ deep $30^{\circ} \mathrm{V}$-notch and a 0.05 - to 0.08 -mm-root radius were machined from normalizedand-tempered $15.9-\mathrm{mm}$ plates. Specimens were machined from along the rolling direction with the notch transverse to the rolling direction (L-T orientation). The absorbed energy values were fit with a hyperbolic tangent function to permit the USE and DBTT to be evaluated. The DBTT was determined at an energy level midway between the upper and lower shelf energies. Details on the test procedure for the subsize Charpy specimens have been published [9].

For each irradiation condition, six Charpy specimens and two tensile specimens from each heat were irradiated in the Materials Open Test Assembly (MOTA) of FFTF in the below-core specimen canister, a sodium "weeper" operating at $\approx 365^{\circ} \mathrm{C}$. Fluence was determined from flux monitors in the irradiation canisters; there was some variation for different specimens, depending on their position in the canister. Specimens were irradiated to $1.7-2.1 \times 10^{26}, 4.2-4.5 \times 10^{26}, 5.9-6.3 \times 10^{26}$, and $5.5-6.3 \times 10^{26} \mathrm{n} / \mathrm{m}^{2}(\mathrm{E}>0.1 \mathrm{MeV})$, which produced 6-8, 15-17, 23-24, and 26-29 dpa, respectively. Helium concentrations were calculated to be less than $1 \mathrm{appm}$.

Tensile and Charpy specimens were aged for 5000,10000 , and $20000 \mathrm{~h}$ at $365^{\circ} \mathrm{C}$, and these specimens along with the unaged specimens (data previously reported) were tested at $365^{\circ} \mathrm{C}$ as controls.

\section{RESULTS}

Tensile and Charpy results will be presented separately. The new results will be presented within the context of the results previously obtained [6-8], so that the effects of irradiation fluence on mechanical property behavior can be analyzed. 


\section{Properties Before and After Thermal Aging}

Tensile Behavior --Aging for 5000,10000 , and $20000 \mathrm{~h}$ at $365^{\circ} \mathrm{C}$ had relatively little effect on yield stress [Fig. 1(a)], ultimate tensile strength [Fig. 1 (b)], uniform elongation [Fig. 1(c)], and total elongation [Fig. 1(d)] (Table 2). Several of the steels showed a slight increase in strength (2 1/4CrV, 9Cr-2WV, 9Cr-2WVTa, and 12Cr-2WV), with most of the increase occurring in the first $5000 \mathrm{~h}$. Despite this hardening in the first $5000 \mathrm{~h}$, there was often an increase in ductility after the $5000 \mathrm{~h}$ age, although the elongations displayed considerable scatter. The $21 / 4 \mathrm{CrV}$ and $21 / 4 \mathrm{Cr}-1 \mathrm{WV}$ were the strongest steels, and the $21 / 4 \mathrm{Cr}-2 \mathrm{~W}$ was the weakest (these three steels were tempered at $700^{\circ} \mathrm{C}$ ). Of the five steels tempered at $750^{\circ} \mathrm{C}$, the $21 / 4 \mathrm{Cr}-2 \mathrm{WV}$ was the strongest, and the $5 \mathrm{Cr}-2 \mathrm{WV}$ the weakest. The strengths of the $9 \mathrm{Cr}-2 \mathrm{WV}$ and $9 \mathrm{Cr}-2 \mathrm{WVTa}$ were essentially the same before and after aging.
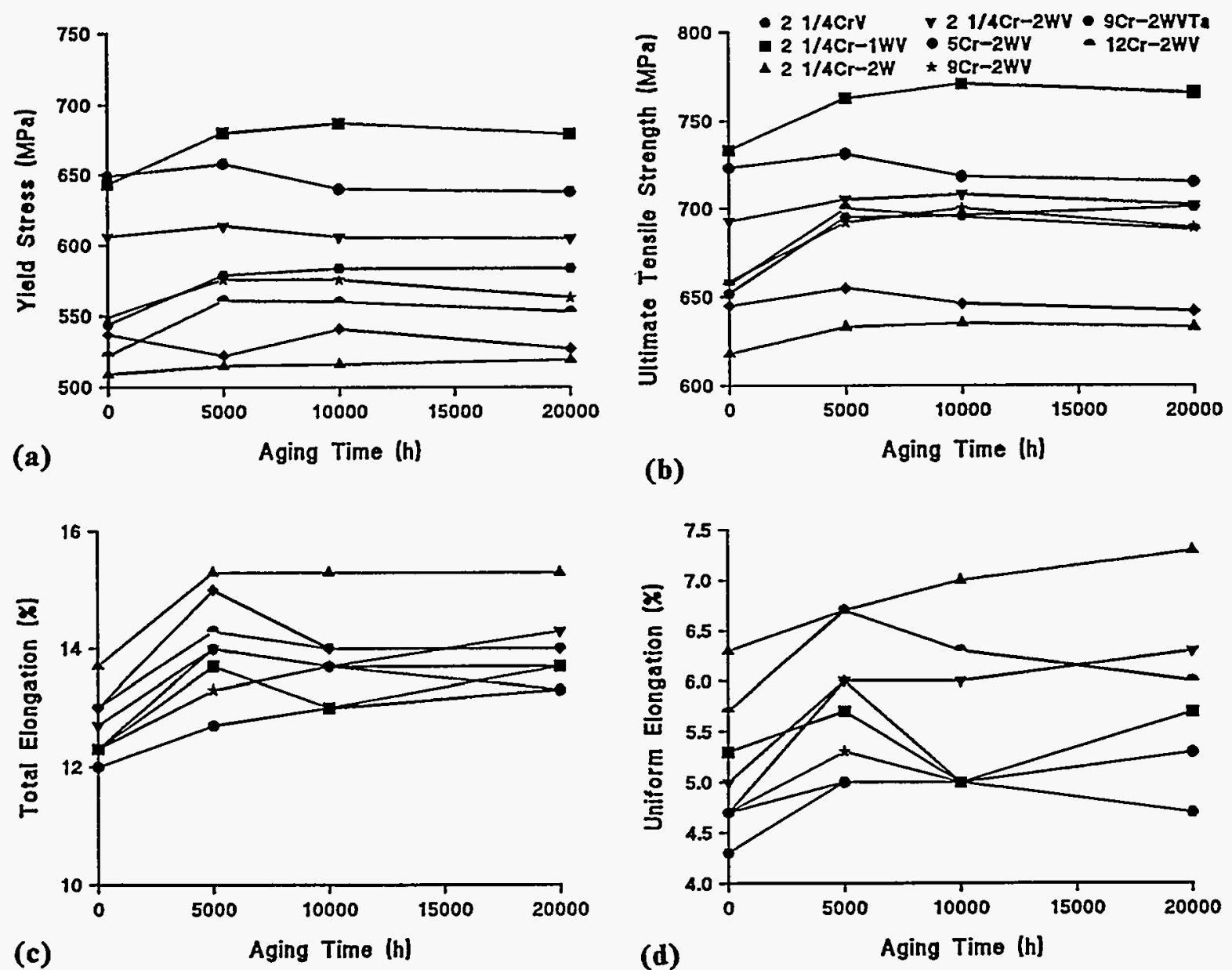

Fig. 1--The (a) yield stress, (b) ultimate tensile strength, (c) uniform elongation, and total elongation as a function of aging time at $365^{\circ} \mathrm{C}$ for the eight reduced-activation steels. 
TABLE 2--Tensile properties of thermally aged reduced-activation steels ${ }^{a}$

\begin{tabular}{|c|c|c|c|c|c|}
\hline \multirow[t]{2}{*}{ Steel } & \multirow{2}{*}{$\begin{array}{l}\text { Aging Time } \\
\text { (h) }\end{array}$} & \multicolumn{2}{|c|}{ Strength (Mpa) } & \multicolumn{2}{|c|}{ Elongation (\%) } \\
\hline & & Yield & Ultimate & Uniform & Total \\
\hline \multirow[t]{4}{*}{$2 \mathrm{l} / 4 \mathrm{CrV}$} & 0 & 649 & 723 & 4.7 & 12.0 \\
\hline & 5000 & 658 & 731 & 5.0 & 12.7 \\
\hline & 10000 & 640 & 718 & 5.0 & 13.0 \\
\hline & 20000 & 638 & 715 & 5.3 & 13.3 \\
\hline \multirow[t]{4}{*}{$21 / 4 C r-1 W V$} & 0 & 643 & 733 & 5.3 & 12.3 \\
\hline & 5000 & 680 & 763 & 5.7 & 13.7 \\
\hline & 10000 & 687 & 771 & 5.0 & 13.0 \\
\hline & 20000 & 679 & 766 & 5.7 & 13.7 \\
\hline \multirow[t]{4}{*}{$21 / 4 C r-2 W$} & 0 & 509 & 618 & 6.3 & 13.7 \\
\hline & 5000 & 515 & 633 & 6.7 & 15.3 \\
\hline & 10000 & 516 & 635 & 7.0 & 15.3 \\
\hline & 20000 & 519 & 633 & 7.3 & 15.3 \\
\hline \multirow[t]{4}{*}{$21 / 4 \mathrm{Cr}-2 \mathrm{WV}$} & 0 & 606 & 693 & 5.0 & 12.7 \\
\hline & 5000 & 614 & 705 & 6.0 & 14.0 \\
\hline & 10000 & 606 & 708 & 6.0 & 13.7 \\
\hline & 20000 & 605 & 702 & 6.3 & 14.3 \\
\hline \multirow[t]{4}{*}{$5 \mathrm{Cr}-2 \mathrm{WV}$} & 0 & 537 & 645 & 4.7 & 13.0 \\
\hline & 5000 & 522 & 655 & 6.0 & 15.0 \\
\hline & 10000 & 541 & 646 & 5.0 & 14.0 \\
\hline & 20000 & 527 & 642 & 5.3 & 14.0 \\
\hline \multirow[t]{4}{*}{$9 \mathrm{Cr}-2 \mathrm{WV}$} & 0 & 549 & 659 & 4.7 & 12.3 \\
\hline & 5000 & 576 & 692 & 5.3 & 13.3 \\
\hline & 10000 & 576 & 700 & 5.0 & 13.7 \\
\hline & 20000 & 563 & 689 & 5.3 & 13.7 \\
\hline \multirow{4}{*}{ 9Cr-2WVTa } & 0 & 544 & 652 & 4.3 & 12.3 \\
\hline & 5000 & 579 & 695 & 5.0 & 14.0 \\
\hline & 10000 & 584 & 696 & 5.0 & 13.7 \\
\hline & 20000 & 584 & 701 & 4.7 & 13.3 \\
\hline \multirow{4}{*}{$12 \mathrm{Cr}-2 \mathrm{WV}$} & 0 & 522 & 657 & 5.7 & 13.0 \\
\hline & 5000 & 561 & 700 & 6.7 & 14.3 \\
\hline & 10000 & 560 & 695 & 6.3 & 14.0 \\
\hline & 20000 & 553 & 688 & 6.0 & 14.0 \\
\hline
\end{tabular}

${ }^{a}$ Values are the average of two tests 
Charpy Behavior--Charpy impact properties showed relatively little change after aging for $0,5000,10000$, and $20000 \mathrm{~h}$ at $365^{\circ} \mathrm{C}$ (Table 3). The DBTT values [Fig. 2(a)] for several of the the steels showed a slight change, usually in the initial $5000 \mathrm{~h}$. The $9 \mathrm{Cr}$ 2WVTa had the lowest DBTT, and the four $21 / 4 \mathrm{Cr}$ steels and the 12Cr-2WV steel had the highest values. The USE [Fig. 2(b)] of most of the steels showed an increase with aging time with the largest change usually occurring within the first $5000 \mathrm{~h}$. The $9 \mathrm{Cr}$ $2 \mathrm{WVTa}$ steel had the highest USE after $10000 \mathrm{~h}$, but then decreased at $20000 \mathrm{~h}$ to a value similar to values for the other steels.

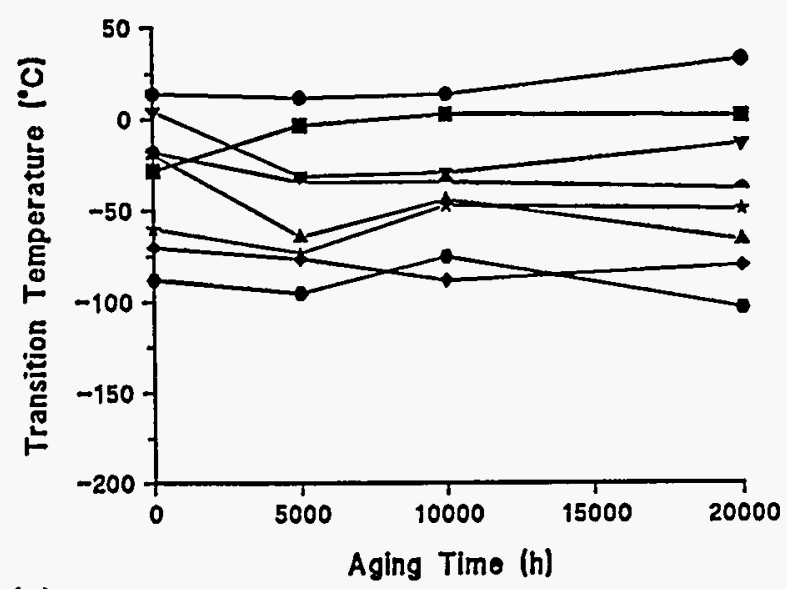

(a)

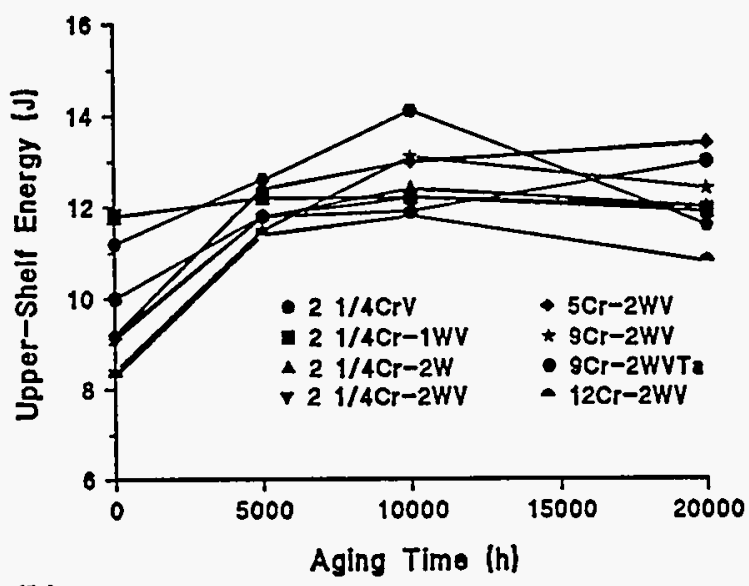

(b)

Fig. 2--The (a) ductile-brittle transition temperature and (b) upper-shelf energy as a function of aging time at $365^{\circ} \mathrm{C}$ for the eight reduced-activation steels.

\section{Properties After Irradiation}

Tensile behavior--Irradiation hardened the steels (Table 4), as measured by the yield stress [Fig. 3(a)] and ultimate tensile strength [Fig. 3(b)]. Hardening appeared to saturate with fluence, although the curve for the $21 / 4 \mathrm{CrV}$ appeared to go through a maximum. For this discussion, the results are concluded to indicate saturation; that is, there was a strength increase during the first increment of irradiation, after which it remained essentially constant with further irradiation. The curves for strength after irradiation fell into two groups: the $21 / 4 \mathrm{Cr}-2 \mathrm{~W}, 5 \mathrm{Cr}-2 \mathrm{WV}, 9 \mathrm{Cr}-2 \mathrm{WV}$, and $9 \mathrm{Cr}-2 \mathrm{WVTa}$ fell into a group showing the lowest strength and the $21 / 4 \mathrm{CrV}, 21 / 4 \mathrm{Cr}-1 \mathrm{WV}, 21 / 4 \mathrm{Cr}-2 \mathrm{WV}$, and $12 \mathrm{Cr}$ $2 \mathrm{WV}$ fell in a group showing a considerably higher strength. The two $9 \mathrm{Cr}$ steels had the lowest strength after irradiation.

Uniform [Fig. 3(c)] and total elongation [Fig. 3(d)] decreased with fluence. As opposed to the separation into two groups observed for the strength, the ductility appeared to fall into three groups. The $9 \mathrm{Cr}-2 \mathrm{WV}$ and $9 \mathrm{Cr}-2 \mathrm{WVTa}$ steels had the highest ductility after irradiation, followed by the $21 / 4 \mathrm{Cr}-2 \mathrm{~W}$ and $5 \mathrm{Cr}-2 \mathrm{WV}$, and then the third group containing the $21 / 4 \mathrm{CrV}, 21 / 4 \mathrm{Cr}-1 \mathrm{WV}, 21 / 4 \mathrm{Cr}-2 \mathrm{WV}$, and $12 \mathrm{Cr}-2 \mathrm{WV}$. Although 
TABLE 3--Charpy impact properties of thermally aged reduced-activation steels

\begin{tabular}{|c|c|c|c|}
\hline Steel & $\begin{array}{l}\text { Aging Time } \\
\text { (h) }\end{array}$ & $\begin{array}{l}\text { DBTT }^{\text {a }} \\
\left({ }^{\circ} \mathrm{C}\right)\end{array}$ & $\begin{array}{c}\text { Upper-Shelf } \\
\text { Energy (J) }\end{array}$ \\
\hline \multirow{4}{*}{$2 \mathrm{l} / 4 \mathrm{CrV}$} & 0 & 14 & 10.0 \\
\hline & 5000 & 12 & 11.8 \\
\hline & 10000 & 14 & 11.9 \\
\hline & 20000 & 33 & 13.0 \\
\hline \multirow[t]{4}{*}{$21 / 4 \mathrm{Cr}-1 \mathrm{WV}$} & 0 & -28 & 11.8 \\
\hline & 5000 & -3 & 12.2 \\
\hline & 10000 & 3 & 12.2 \\
\hline & 20000 & 2 & 11.9 \\
\hline \multirow[t]{4}{*}{$21 / 4 \mathrm{Cr}-2 \mathrm{~W}$} & 0 & -19 & 9.2 \\
\hline & 5000 & -64 & 11.8 \\
\hline & 10000 & -44 & 12.4 \\
\hline & 20000 & -66 & 12.0 \\
\hline \multirow[t]{4}{*}{$21 / 4 \mathrm{Cr}-2 \mathrm{WV}$} & 0 & 4 & 9.1 \\
\hline & 5000 & -31 & 11.8 \\
\hline & 10000 & -29 & 12.2 \\
\hline & 20000 & -13 & 12.0 \\
\hline \multirow[t]{4}{*}{$5 \mathrm{Cr}-2 \mathrm{WV}$} & 0 & -70 & 9.2 \\
\hline & 5000 & -76 & 12.4 \\
\hline & 10000 & -88 & 13.0 \\
\hline & 20000 & -80 & 13.4 \\
\hline \multirow[t]{4}{*}{$9 \mathrm{Cr}-2 \mathrm{WV}$} & 0 & -60 & 8.4 \\
\hline & 5000 & -73 & 11.5 \\
\hline & 10000 & -47 & 13.1 \\
\hline & 20000 & -49 & 12.4 \\
\hline \multirow[t]{4}{*}{$9 \mathrm{Cr}-2 \mathrm{WVTa}$} & 0 & -88 & 11.2 \\
\hline & 5000 & -95 & 12.6 \\
\hline & 10000 & -75 & 14.1 \\
\hline & 20000 & -103 & 11.6 \\
\hline \multirow[t]{4}{*}{$12 \mathrm{Cr}-2 \mathrm{WV}$} & 0 & -18 & 8.3 \\
\hline & 5000 & -34 & 11.4 \\
\hline & 10000 & -34 & 11.8 \\
\hline & 20000 & -38 & 10.8 \\
\hline
\end{tabular}

${ }^{\mathrm{a}}$ Evaluated at an energy level halfway between the upper and lower shelves

the ductility data showed considerable scatter, the decrease in uniform elongation appeared to saturate with fluence. 

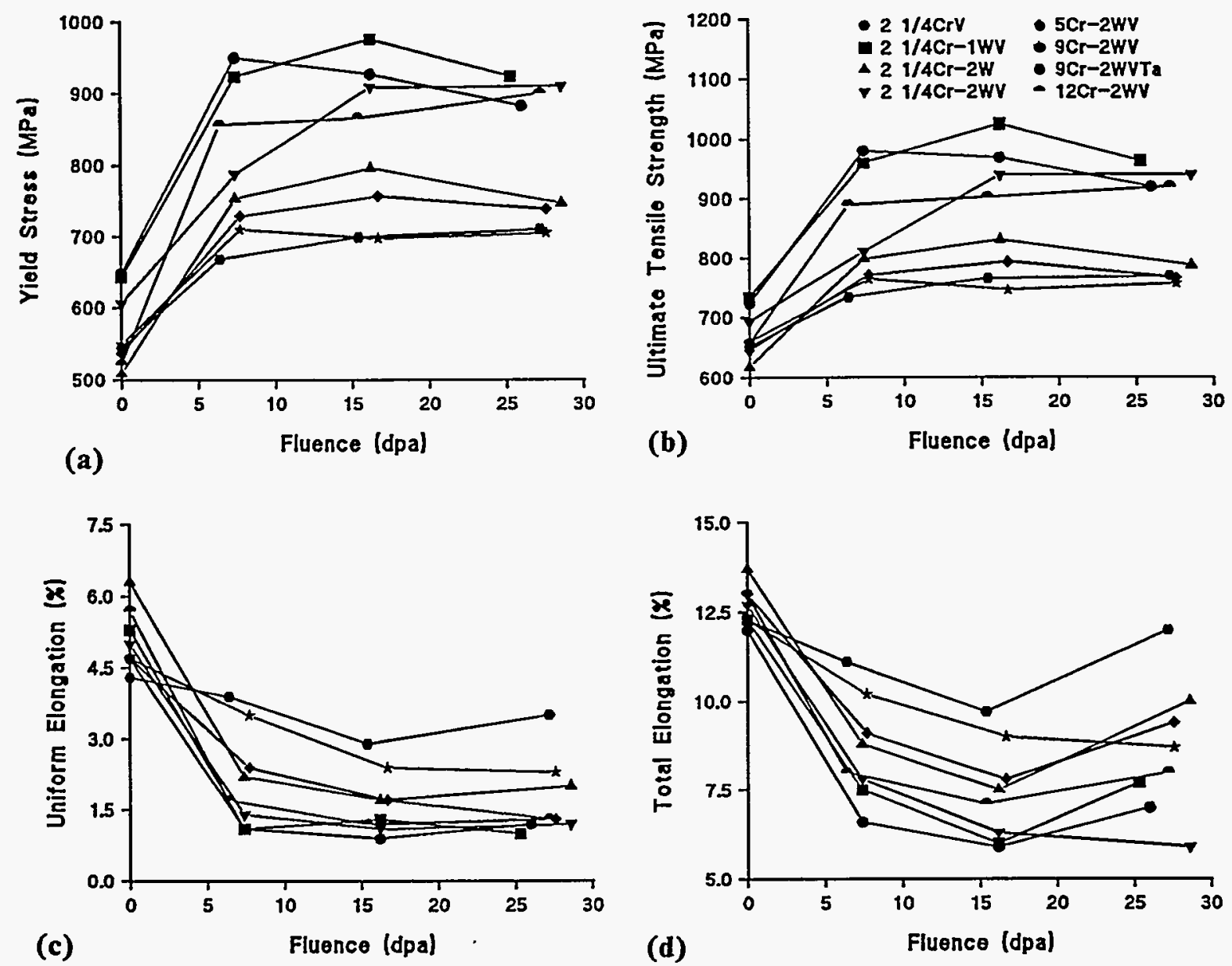

Fig. 3--The (a) yield stress, (b) ultimate tensile strength, (c) uniform elongation, and (d) total elongation as a function of fluence for the eight reduced-activation steels irradiated in FFTF at $365^{\circ} \mathrm{C}$.

Charpy Behavior--The Charpy data for irradiations up to 26-29 dpa continued the trends noted for the previous irradiations (Table 5) [6-8]. After an initial increase in DBTT with fluence [Fig. 4(a)], the change in DBTT of most of the steels appeared to level off with increasing fluence, indicating an approach to a saturation in the shift in DBTT $(\triangle D B T T)$. The only exception was the $9 \mathrm{Cr}-2 \mathrm{WVTa}$, which showed a continuous increase in DBTT over the entire fluence range, although the increase was slight. Despite the slight increase, it was obvious that the 9Cr-2WVTa showed superior behavior at all fluences. The $9 \mathrm{Cr}-2 \mathrm{WV}$ and the $5 \mathrm{Cr}-2 \mathrm{WV}$ steels showed the next best behavior. 
TABLE 4--Tensile properties of Cr-W steels irradiated in FFTF at $365^{\circ} \mathrm{C}^{3}$

\begin{tabular}{|c|c|c|c|c|c|}
\hline \multirow{2}{*}{ Steel } & \multirow{2}{*}{$\begin{array}{l}\text { Fluence } \\
\text { (dpa) }\end{array}$} & \multicolumn{2}{|c|}{ Strength (Mpa) } & \multicolumn{2}{|c|}{ Elongation (\%) } \\
\hline & & Yield & Ultimate & Uniform & Total \\
\hline \multirow[t]{4}{*}{$21 / 4 \mathrm{CrV}$} & 0 & 649 & 723 & 4.7 & 12.0 \\
\hline & 7.4 & 950 & 980 & 1.1 & 6.4 \\
\hline & 16.2 & 937 & 968 & 0.9 & 7.0 \\
\hline & 26.0 & 883 & 920 & 1.2 & 7.0 \\
\hline \multirow[t]{4}{*}{$21 / 4 \mathrm{Cr}-1 \mathrm{WV}$} & 0 & 643 & 733 & 5.3 & 12.3 \\
\hline & 7.4 & 924 & 959 & 1.3 & 7.5 \\
\hline & 16.2 & 976 & 1026 & 1.0 & 7.5 \\
\hline & 25.4 & 924 & 963 & 1.4 & 7.7 \\
\hline \multirow[t]{4}{*}{$21 / 4 C r-2 W$} & 0 & 509 & 618 & 6.3 & 13.7 \\
\hline & 7.4 & 754 & 799 & 2.2 & 8.8 \\
\hline & 16.2 & 796 & 830 & 1.7 & 7.5 \\
\hline & 28.6 & 747 & 787 & 2.0 & 10.0 \\
\hline \multirow[t]{4}{*}{$21 / 4 \mathrm{Cr}-2 \mathrm{WV}$} & 0 & 606 & 693 & 5.0 & 12.7 \\
\hline & 7.4 & 788 & 810 & 1.4 & 7.8 \\
\hline & 16.2 & 909 & 939 & 1.1 & 5.3 \\
\hline & 28.6 & 910 & 940 & 1.2 & 5.9 \\
\hline \multirow[t]{4}{*}{$5 \mathrm{Cr}-2 \mathrm{WV}$} & 0 & 537 & 645 & 4.7 & 13.0 \\
\hline & 7.7 & 729 & 771 & 2.4 & 9.1 \\
\hline & 16.7 & 757 & 793 & 1.7 & 7.8 \\
\hline & 27.6 & 739 & 766 & 1.4 & 11.2 \\
\hline \multirow{4}{*}{$9 \mathrm{Cr}-2 \mathrm{WV}$} & 0 & 549 & 659 & 4.7 & 12.3 \\
\hline & 7.7 & 710 & 764 & 3.5 & 10.2 \\
\hline & 16.7 & 697 & 745 & 2.3 & 9.0 \\
\hline & 27.6 & 705 & 756 & 2.3 & 8.7 \\
\hline \multirow{4}{*}{$9 \mathrm{Cr}-2 \mathrm{WVTa}$} & 0 & 544 & 652 & 4.3 & 12.3 \\
\hline & 6.4 & 669 & 734 & 3.9 & 11.1 \\
\hline & 15.4 & 699 & 765 & 2.9 & 9.7 \\
\hline & 27.2 & 710 & 769 & 3.5 & 12.0 \\
\hline \multirow{4}{*}{$12 \mathrm{Cr}-2 \mathrm{WV}$} & 0 & 522 & 657 & 5.7 & 13.0 \\
\hline & 6.4 & 857 & 890 & 1.7 & 8.0 \\
\hline & 15.4 & 866 & 902 & 1.2 & 7.1 \\
\hline & 27.2 & 900 & 932 & 1.3 & 8.0 \\
\hline
\end{tabular}

a Values are the average of two tests

The USE [Fig. 4(b)] decreased with fluence and leveled off (saturated), although for several steels it decreased slightly between the third and fourth irradiations. By far the best steel was the $9 \mathrm{Cr}-2 \mathrm{WVTa}$, with the $9 \mathrm{Cr}-2 \mathrm{WV}$ and $5 \mathrm{Cr}-2 \mathrm{WV}$ second best. Comparison of Charpy curves for the two most irradiation-resistant steels indicates the superiority of the $9 \mathrm{Cr}-2 \mathrm{WVTa}$ steel by showing that the curves for the $9 \mathrm{Cr}-2 \mathrm{WVTa}$ [Fig. 5(a)] after irradiation approach the curve for the unirradiated 9Cr-2WV steel [Fig. 5(b)]. 

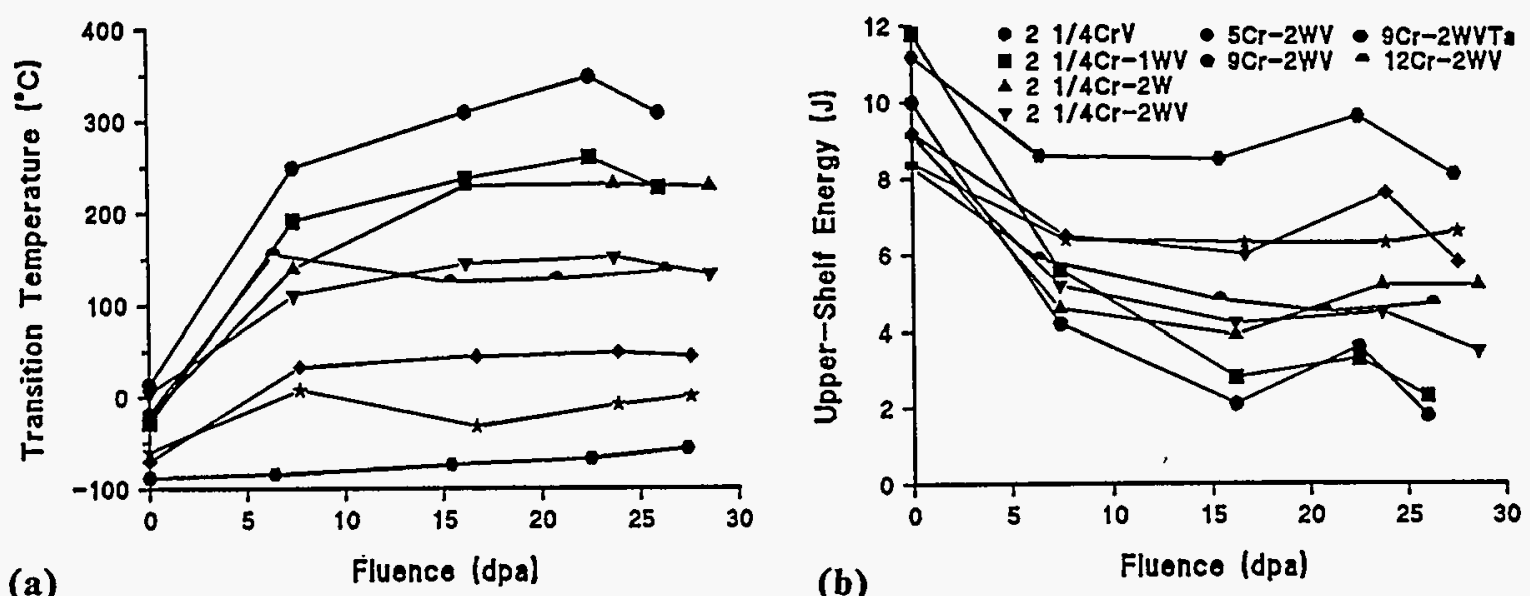

Fig. 4--The (a) ductile-brittle transition temperature and (b) upper-shelf energy as a function of fluence for the eight reduced-activation steels irradiated in FFTF at $365^{\circ} \mathrm{C}$.

Large increases in DBTT and large decreases in USE ( $\triangle$ USE) were observed for the four low-chromium steels and the 12Cr-2WV. The behavior of the $21 / 4 \mathrm{Cr}-2 \mathrm{WV}$ and $12 \mathrm{Cr}-2 \mathrm{WV}$ were comparable and displayed the smallest change in DBTT of these five steels. The $21 / 4 \mathrm{CrV}$ had the largest $\triangle \mathrm{DBTT}$ and $\triangle \mathrm{USE}$, followed by the $21 / 4 \mathrm{Cr}-1 \mathrm{WV}$ and the $21 / 4 \mathrm{Cr}-2 \mathrm{~W}$, although the USE of the latter steel at the highest fluences was comparable to that of the $21 / 4 \mathrm{Cr}-2 \mathrm{WV}$ and $12 \mathrm{Cr}-2 \mathrm{WV}$. The difference between the best and worst of the steels can be seen by comparing the curves for $21 / 4 \mathrm{CrV}$ [Fig. 5(c)] with those for $9 \mathrm{Cr}-2 \mathrm{WV}$ [Fig. 5(a)] and 9Cr-2WVTa in [Fig. 5(b)].

\section{DISCUSSION}

\section{Properties Before and After Thermal Aging}

The microstructures of the normalized-and-tempered 0.76-mm sheets and 15.9-mm plates from which tensile and Charpy specimens were taken, respectively, have been examined [3]. There was a difference in microstructure of the $21 / 4 \mathrm{Cr}$ steels in the two geometries. All of these low-chromium steels were $\approx 100 \%$ bainite when heat treated as $0.76-\mathrm{mm}$ sheet. When heat treated as $15.9-\mathrm{mm}$ plate, all but the $21 / 4 \mathrm{Cr}-2 \mathrm{~W}$ steel contained a duplex microstructure of tempered bainite and polygonal ferrite: $21 / 4 \mathrm{CrV}$ [Fig.6(a)] contained $\approx 30 \%$ tempered bainite, $70 \%$ ferrite; $21 / 4 \mathrm{Cr}-1 \mathrm{WV}$ [Fig. 6(b)] contained $\approx 55 \%$ tempered bainite, $45 \%$ ferrite; and $21 / 4 \mathrm{Cr}-2 \mathrm{WV}$ [Fig. 6(d)] was $\approx 80 \%$ tempered bainite, $20 \%$ ferrite. The $21 / 4 \mathrm{Cr}-2 \mathrm{~W}$ steel [Fig. 6 (c)] was $100 \%$ tempered bainite. Microstructures were the same for the high-chromium steels in both geometries: the 5Cr-2WV [Fig. 7(a)], 9Cr-2WV [Fig. 7(b)], and 9Cr-2WVTa [Fig 7(c)] steels were 
(a)

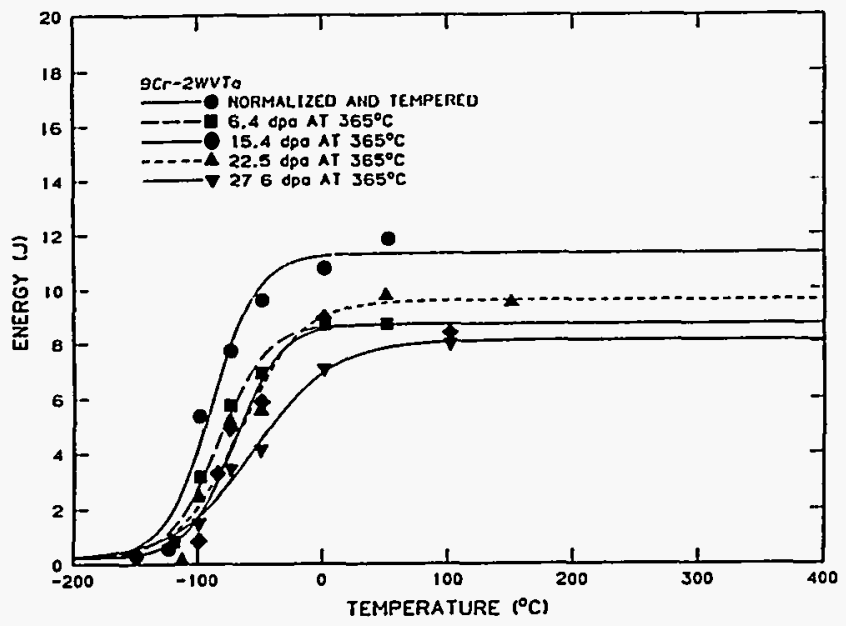

(b)

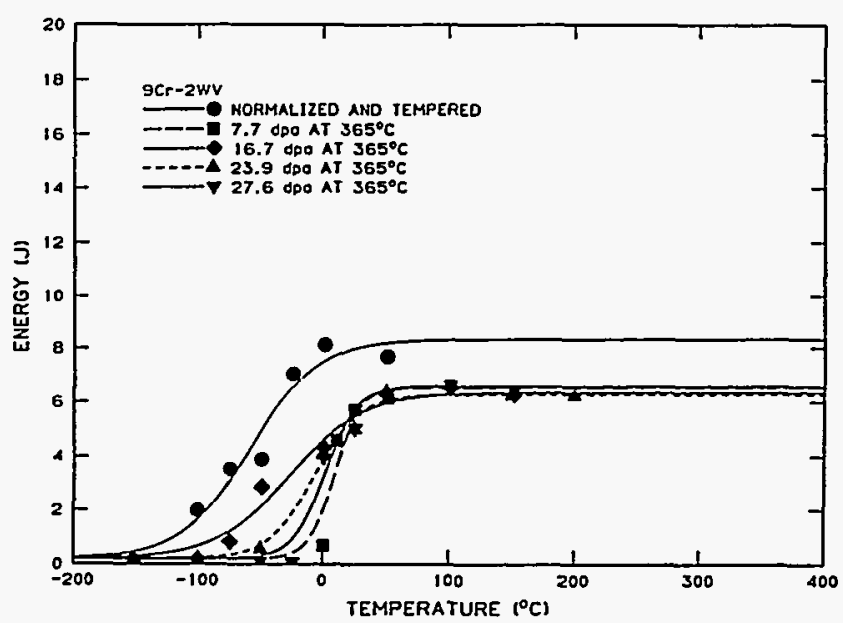

(c)

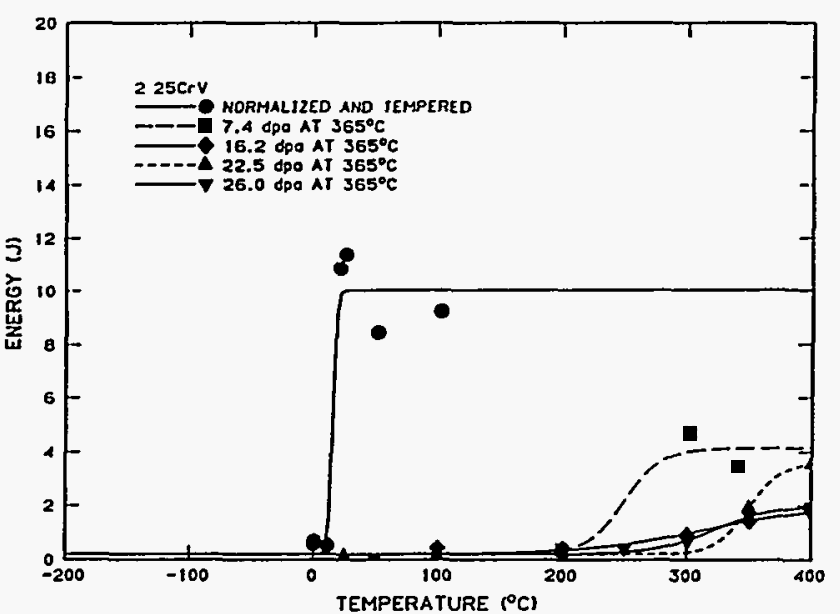

Fig. 5-Charpy curves for the normalized-and-tempered and irradiated (a) $9 \mathrm{Cr}-2 \mathrm{WVTa}$, (b) $9 \mathrm{Cr}-2 \mathrm{WV}$ steels, and (c) $21 / 4 \mathrm{CrV}$. 
TABLE 5--Charpy impact properties of $\mathrm{Cr}-\mathrm{W}$ steels irradiated in FFTF at $365^{\circ} \mathrm{C}$

\begin{tabular}{|c|c|c|c|c|c|c|}
\hline Steel & $\begin{array}{l}\text { Fluence } \\
\text { (dpa) }\end{array}$ & $\begin{array}{l}\text { DBTT } \\
\left({ }^{\circ} \mathrm{C}\right)\end{array}$ & $\begin{array}{c}\triangle \mathrm{DBTT} \\
\left({ }^{\circ} \mathrm{C}\right)\end{array}$ & $\begin{array}{c}\text { Upper-Shelf } \\
\text { Energy }(\mathrm{J})\end{array}$ & $\begin{array}{c}\begin{array}{l}\Delta U S E \\
(\%)\end{array} \\
\end{array}$ & $\begin{array}{l}\Delta \sigma_{y} \\
(\%)\end{array}$ \\
\hline \multirow{5}{*}{$21 / 4 \mathrm{CrV}$} & 0 & 14 & & 10.0 & & \\
\hline & 7.4 & 250 & 236 & 4.2 & -58 & 46 \\
\hline & 16.2 & 310 & 296 & 2.1 & -79 & 44 \\
\hline & 22.5 & 349 & 335 & 3.6 & -64 & \\
\hline & 26.0 & 309 & 295 & 1.8 & -82 & 36 \\
\hline \multirow[t]{5}{*}{$21 / 4 \mathrm{Cr}-1 \mathrm{WV}$} & 0 & -28 & & 11.8 & & \\
\hline & 7.4 & 192 & 220 & 5.6 & -53 & 44 \\
\hline & 16.2 & 238 & 266 & 2.8 & -76 & 52 \\
\hline & 22.5 & 261 & 289 & 3.3 & -72 & \\
\hline & 26.0 & 228 & 256 & 2.3 & -81 & 44 \\
\hline \multirow[t]{5}{*}{$21 / 4 \mathrm{Cr}-2 \mathrm{~W}$} & 0 & -19 & & 9.2 & & \\
\hline & 7.4 & 140 & 159 & 4.6 & -50 & 48 \\
\hline & 16.2 & 230 & 249 & 3.9 & -58 & 56 \\
\hline & 23.7 & 232 & 251 & 5.2 & -43 & \\
\hline & 28.6 & 229 & 248 & 5.2 & -43 & 47 \\
\hline \multirow{5}{*}{$21 / 4 \mathrm{Cr}-2 \mathrm{WV}$} & 0 & 4 & & 9.1 & & \\
\hline & 7.4 & 111 & 107 & 5.2 & -43 & 30 \\
\hline & 16.2 & 145 & 141 & 4.2 & -54 & 50 \\
\hline & 23.7 & 152 & 148 & 4.5 & -51 & \\
\hline & 28.6 & 133 & 129 & 3.5 & -62 & 50 \\
\hline \multirow[t]{5}{*}{$5 \mathrm{Cr}-2 \mathrm{WV}$} & 0 & -70 & & 9.2 & & \\
\hline & 7.7 & 33 & 103 & 6.5 & -29 & 36 \\
\hline & 16.7 & 45 & 115 & 6.0 & -35 & 41 \\
\hline & 23.9 & 49 & 119 & 7.6 & -17 & \\
\hline & 27.6 & 45 & 115 & 5.8 & -37 & 38 \\
\hline \multirow[t]{5}{*}{$9 \mathrm{Cr}-2 \mathrm{WV}$} & 0 & -60 & & 8.4 & & \\
\hline & 7.7 & 8 & 68 & 6.4 & -24 & 30 \\
\hline & 16.7 & -32 & 28 & 6.3 & -25 & 27 \\
\hline & 23.9 & -8 & 52 & 6.3 & -25 & \\
\hline & 27.6 & 1 & 61 & 6.6 & -21 & 28 \\
\hline \multirow{5}{*}{$9 \mathrm{Cr}-2 \mathrm{WVTa}$} & 0 & -88 & & 11.2 & & \\
\hline & 6.4 & -84 & 4 & 8.6 & -23 & 23 \\
\hline & 15.4 & -74 & 14 & 8.5 & -24 & 28 \\
\hline & 22.5 & -67 & 21 & 9.6 & -14 & \\
\hline & 27.6 & -56 & 32 & 8.1 & -28 & 31 \\
\hline \multirow[t]{5}{*}{$12 \mathrm{Cr}-2 \mathrm{WV}$} & 0 & -18 & & 8.3 & & \\
\hline & 6.4 & 156 & 174 & 5.9 & -29 & 64 \\
\hline & 15.4 & 125 & 143 & 4.8 & -42 & 66 \\
\hline & 20.8 & 128 & 146 & 4.5 & -46 & \\
\hline & 26.3 & 137 & 155 & 4.7 & -43 & $\underline{72}$ \\
\hline
\end{tabular}

${ }^{a}$ Evaluated at an energy level halfway between the upper and lower shelves 

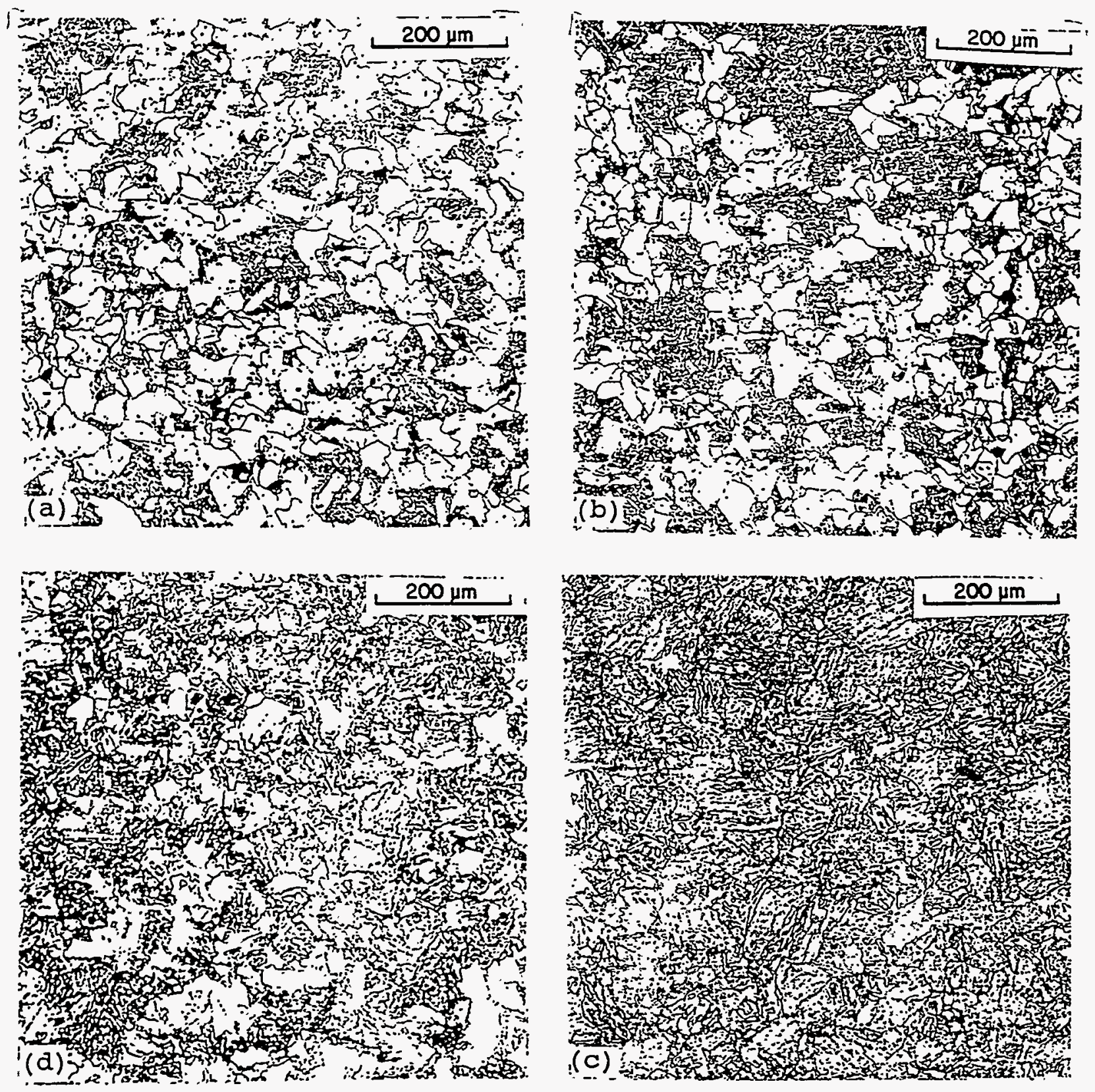

Fig. 6--Normalized-and-tempered microstructures of (a) $21 / 4 \mathrm{CrV}$, (b) $21 / 4 \mathrm{Cr}-1 \mathrm{WV}$, (c) $21 / 4 \mathrm{Cr}-2 \mathrm{~W}$, and (d) $21 / 4 \mathrm{Cr}-2 \mathrm{WV}$ steels.

$100 \%$ tempered martensite, and the 12Cr-2WV [Fig. 7(d)] steel was tempered martensite with $\approx 25 \% \delta$-ferrite []ㅡ.

Before irradiation, the three $21 / 4 \mathrm{Cr}$ steels with vanadium contained $\mathrm{M}_{7} \mathrm{C}_{3}, \mathrm{M}_{3} \mathrm{C}$, and $\mathrm{MC}$ precipitates [3]. The $21 / 4 \mathrm{Cr}-2 \mathrm{~W}$ contained $\mathrm{M}_{7} \mathrm{C}_{3}, \mathrm{M}_{3} \mathrm{C}, \mathrm{M}_{23} \mathrm{C}_{6}$, and $\mathrm{M}_{2} \mathrm{X}$. The $9 \mathrm{Cr}$ $2 \mathrm{WV}, 9 \mathrm{Cr}-2 \mathrm{WVTa}$, and $12 \mathrm{Cr}-2 \mathrm{WV}$ contained primarily $\mathrm{M}_{23} \mathrm{C}_{6}$ and small amounts of $\mathrm{MC}$; some of the $\mathrm{MC}$ in the $9 \mathrm{Cr}-2 \mathrm{WVTa}$ contained tantalum, although most was vanadium 

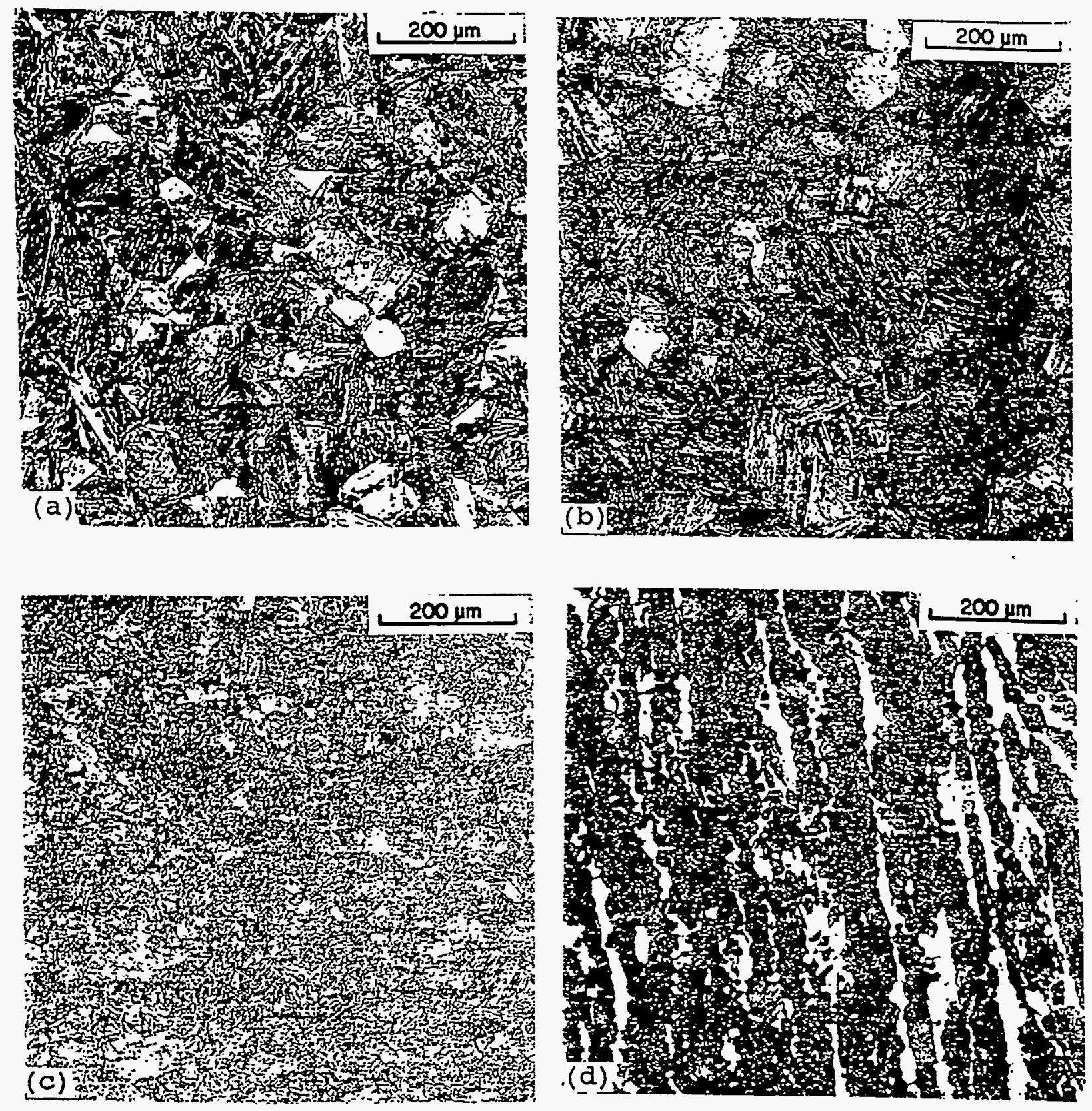

Fig. 7--Normalized-and-tempered microstructures of (a) $5 \mathrm{Cr}-2 \mathrm{WV}$, (b) $9 \mathrm{Cr}-2 \mathrm{WV}$, (c) 9Cr-2WVTa, and (d) $12 \mathrm{Cr}-2 \mathrm{WV}$ steels.

rich, as it was in the $9 \mathrm{Cr}-2 \mathrm{WV}$. The $5 \mathrm{Cr}-2 \mathrm{WV}$ contained mainly $\mathrm{M}_{7} \mathrm{C}_{3}$, with small amounts of $\mathrm{M}_{23} \mathrm{C}_{6}$ and $\mathrm{MC}$, thus bridging the gap between the $\mathrm{M}_{7} \mathrm{C}_{3}$ found in the steels with $21 / 4 \% \mathrm{Cr}$ and the $\mathrm{M}_{23} \mathrm{C}_{6}$ found in the steels with $9 \% \mathrm{Cr}[\underline{3}]$.

The relative strengths of the steels before aging or irradiation [Figs. 1(a) and 1(b)] were the result of the heat treatment given the steels. The $21 / 4 \mathrm{CrV}$ and $21 / 4 \mathrm{Cr}-1 \mathrm{WV}$ were stronger than the other steels because these steels were tempered at $700^{\circ} \mathrm{C}$, while all 
but the $21 / 4 \mathrm{Cr}-2 \mathrm{~W}$ were tempered at $750^{\circ} \mathrm{C}$. The $21 / 4 \mathrm{Cr}-2 \mathrm{~W}$ was the weakest, despite being tempered at $700^{\circ} \mathrm{C}$, because it did not contain the strong carbide-forming element vanadium, and thus, it was not strengthened by $\mathrm{MC}$. Of the steels that contained vanadium and were tempered at $750^{\circ} \mathrm{C}$, the $21 / 4 \mathrm{Cr}-2 \mathrm{WV}$ was the strongest, followed by $9 \mathrm{Cr}$ 2WVTa, 9Cr-2WV, 12Cr-2WV, and the $5 \mathrm{Cr}-2 \mathrm{WV}$ steels. There was essentially no difference in the strength of the $9 \mathrm{Cr}-2 \mathrm{WV}$ and the $9 \mathrm{Cr}-2 \mathrm{WVT}$ in the unirradiated condition. All of the steels had adequate ductility [Figs. 1(b) and 1(c)]. Aging at $365^{\circ} \mathrm{C}$ to $20000 \mathrm{~h}$ had little effect on strength and ductility of any of the steels; properties remained similar or slightly improved compared to the unaged steel.

Thermal aging had little effect on the DBTT of the steels [Fig. 2(a) ]. However, the DBTT behavior of the unirradiated steels after thermal aging reflected the different microstructures. Steels with a $100 \%$ tempered martensite and a $100 \%$ tempered bainite microstructure--the 5Cr-2WV, 9Cr-2WV, 9Cr-2WVTa and $21 / 4 \mathrm{Cr}-2 \mathrm{~W}$--had the lowest DBTT values. The other four steels had duplex microstructures, each containing some polygonal or delta ferrite. The DBTT values increased with increasing amount of ferrite, from the $12 \mathrm{Cr}-2 \mathrm{WV}$ and $21 / 4 \mathrm{Cr}-2 \mathrm{WV}$, with $20-25 \%$, to the $21 / 4 \mathrm{Cr}-1 \mathrm{WV}$, with $\approx 45 \%$, and the $21 / 4 \mathrm{CrV}$, with $\approx 70 \%$ ferrite.

The USE of most of the steels increased slightly during aging, especially during the initial $5000 \mathrm{~h}$ period. The reason for this is not known, although a slight supersaturation of carbon may have been present from the tempering treatment, which is relieved by the low-temperature aging treatment. Little diffusion of any substitutional elements would be expected at $365^{\circ} \mathrm{C}$.

\section{Properties After Irradiation}

Irradiation hardening saturated with fluence with the amount of hardening depending on microstructure [Fig. 3(a) and (b)]. By comparing the relative increase in yield stress, $\Delta \sigma_{y}$ (Table 5) for the different steels, it is seen that the steels with $100 \%$ tempered martensite (5Cr-2WV, $9 \mathrm{Cr}-2 \mathrm{WV}$, and $9 \mathrm{Cr}-2 \mathrm{WVTa}$ ) hardened the least. The $\Delta \sigma_{\mathrm{y}}$ of the two $9 \mathrm{Cr}$ steels was the lowest $(\approx 30 \%$ increase), with that for the $5 \mathrm{Cr}$ steel slightly higher $(35-40 \%)$. The four $21 / 4 \mathrm{Cr}$ steels, which had $100 \%$ bainite microstructures in the tensile specimens, hardened about the same amount (40-50\%), even though they had different strengths before irradiation. Therefore, it appears that tempered bainite hardens more than tempered martensite. The $12 \mathrm{Cr}-2 \mathrm{WV}$ steel contained $\approx 75 \%$ tempered martensite, and it hardened the most (60-70\%), suggesting that the difference between this steel and the $100 \%$ tempered martensitic steels must have been the $25 \% \delta$-ferrite present in the microstructure. The effect of fluence on ductility was inverse to the hardening in that an increase in hardening was accompanied by a decrease in ductility [Fig. 3(c) and 3(d)].

Despite the difference in microstructure of the $21 / 4 \mathrm{Cr}$ steels used for the tensile and Charpy specimens, the effect of fluence on Charpy impact behavior was generally similar to the effect on strength. With the exception of the 9Cr-2WVTa, which appeared to show a slight increase with fluence (this will be discussed below), the effect of irradiation on the DBTT and USE saturated with fluence. Irradiation had the least effect on the DBTT and USE of the three $100 \%$ martensitic steels. Of these, the $9 \mathrm{Cr}-2 \mathrm{WVTa}$ was superior to the other steels, followed by $9 \mathrm{Cr}-2 \mathrm{WV}$ and $5 \mathrm{Cr}-2 \mathrm{WV}$, in agreement with the previous results 
[6-8]. The steels with the next best irradiation resistance were the $21 / 4 \mathrm{Cr}-2 \mathrm{WV}$ and the 12Cr-2WV steels, which contained $20-25 \%$ polygonal and delta ferrite, respectively. These steels saturated at a similar DBTT and USE, although the $21 / 4 \mathrm{Cr}-2 \mathrm{WV}$ had the lowest $\triangle \mathrm{DBTT}$ (Table 5).

For the $21 / 4 \mathrm{Cr}$ steels containing vanadium and a duplex bainite-polygonal ferrite microstructure, it appeared that the the $\triangle \mathrm{DBTT}$ increased with the amount of ferrite in the microstructure. The $21 / 4 \mathrm{CrV}$ steel, which contained the most ferrite $(\approx 70 \%)$, showed the largest $\triangle \mathrm{DBTT}$, followed by the the $21 / 4 \mathrm{Cr}-1 \mathrm{WV}$ and the $21 / 4 \mathrm{Cr}-2 \mathrm{WV}$, the steels with $\approx 45$ and $25 \%$, respectively. Because of the difference in microstructures in the $21 / 4 \mathrm{Cr}$ steel specimens used in the tensile and Charpy experiments, the relationship between the increase in strength and $\triangle \mathrm{DBTT}$ must be interpolated. By comparing tensile results for the $12 \mathrm{Cr}-2 \mathrm{WV}$ and the other martensitic steels, it appears that hardening was influenced substantially by the amount of ferrite in the microstructure. The similarity of the DBTT for the $12 \mathrm{Cr}-2 \mathrm{WV}$ and $21 / 4 \mathrm{Cr}-2 \mathrm{WV}$ steels, which both contain similar amounts of ferrite, appears to support that conclusion [Fig. 4(a]. Likewise, it is concluded that the relative behavior of the $\triangle \mathrm{DBTT}$ of the $21 / 4 \mathrm{CrV}, 21 / 4 \mathrm{Cr}-1 \mathrm{WV}$, and $21 / 4 \mathrm{Cr}-2 \mathrm{WV}$ is determined by the amount of the polygonal ferrite present in the microstructure.

Anderko et al. [13] showed that for $12 \mathrm{Cr}$ steels containing $\delta$-ferrite, it is $\mathrm{M}_{23} \mathrm{C}_{6}$ on martensite/ $\delta$-ferrite boundaries rather than the $\delta$-ferrite itself that causes a deterioration of the Charpy properties. Considerable $\mathrm{M}_{23} \mathrm{C}_{6}$ forms on the interfaces in the $12 \mathrm{Cr}-2 \mathrm{WV}$ in the unirradiated condition [3], which means that $\mathrm{M}_{23} \mathrm{C}_{6}$ could control fracture in the $12 \mathrm{Cr}$ 2 WV. Precipitates (mainly $\mathrm{M}_{7} \mathrm{C}_{3}$ ) may also control the behavior of the $21 / 4 \mathrm{Cr}-2 \mathrm{WV}$ [ 3 ]. This implies that reducing the size of the precipitates at ferrite/martensite or ferrite/bainite boundaries would be the most likely way to minimize $\triangle \mathrm{DBTT}$. In the $21 / 4 \mathrm{Cr}-2 \mathrm{WV}$, the polygonal ferrite can be eliminated by heat treating. It has been demonstrated that heat treating to produce $100 \%$ bainite significantly lowered the DBTT of unirradiated $21 / 4 \mathrm{Cr}$ 2WV [10].

The results on the $5 \mathrm{Cr}-2 \mathrm{WV}, 9 \mathrm{Cr}-2 \mathrm{WV}$, and $9 \mathrm{Cr}-2 \mathrm{WVTa}$ indicate that tempered martensite is more irradiation resistant than tempered bainite. More information on the irradiation resistance of tempered bainite will become known after Charpy specimens of $21 / 4 \mathrm{Cr}-2 \mathrm{WVstel}$ in the fully bainitic condtion have been irradiated.

The properties of the $21 / 4 \mathrm{Cr}-2 \mathrm{~W}$ appeared anomalous with the other $21 / 4 \mathrm{Cr}$ steels because this steel was $100 \%$ tempered bainite but had a much higher DBTT and $\triangle \mathrm{DBTT}$ than the $21 / 4 \mathrm{Cr}-2 \mathrm{WV}$, which was $25 \%$ ferrite. The DBTT of the irradiated $21 / 4 \mathrm{Cr}-2 \mathrm{~W}$ were similar to those of the $21 / 4 \mathrm{Cr}-1 \mathrm{WV}$, which contained $45 \%$ ferrite. A major difference between the $21 / 4 \mathrm{Cr}-2 \mathrm{WV}$ and $21 / 4 \mathrm{Cr}-2 \mathrm{~W}$ is that the $21 / 4 \mathrm{Cr}-2 \mathrm{~W}$ does not contain vanadium. During irradiation the vanadium-containing carbides are more stable than the $\mathrm{M}_{7} \mathrm{C}_{3}$ and $\mathrm{M}_{3} \mathrm{C}$ that dominate in the $21 / 4 \mathrm{Cr}-2 \mathrm{~W}$ [3]. The larger precipitates in the $21 / 4 \mathrm{Cr}-2 \mathrm{~W}$ after irradiation could enhance its susceptibility to fracture relative to the steels with a more stable precipitate structure (e.g., 2 1/4Cr-2WV).

Similar explanations for the low-chromium steels have previously been used to conclude that for maximum irradiation resistance, these steels containing the combination of tungsten and vanadium must be irradiated in the entirely bainitic condition [10]. It has also been pointed out that the type of bainite formed could play a role in the irradiation resistance. 
The two $9 \mathrm{Cr}$ steels show the least hardening and have the best impact properties after irradiation. The properties of the $9 \mathrm{Cr}-2 \mathrm{WVTa}$ were exceptional after the previous three irradiations, showing only a small $\triangle \mathrm{DBTT}\left(21^{\circ} \mathrm{C}\right.$ after $\left.22.5 \mathrm{dpa}\right)[6-8]$; similar behavior was observed in the present experiment. Not only does it show a very small $\triangle \mathrm{DBTT}$ $\left(32 \mathrm{C}^{\circ}\right)$ after over $27 \mathrm{dpa}$, but because it has such a low DBTT in the unirradiated condition, the DBTT after irradiation remains substantially below that for the other steels. It was pointed out previously that the $\triangle \mathrm{DBTT}$ data for the previous three irradiations for 9Cr-2WVTa indicated that there was a gradual increase in the post-irradiation DBTT with increasing dpa [8]. That trend continued in the present experiment [Fig. 4(a)]. However, even after the $27.4 \mathrm{dpa}$, the DBTT of $-56^{\circ} \mathrm{C}$ for the $9 \mathrm{Cr}-2 \mathrm{WVTa}$ is still comparable to the DBTT of the $9 \mathrm{Cr}-2 \mathrm{WV}$ before irradiation (the $9 \mathrm{Cr}-2 \mathrm{WV}$ had the second lowest DBTT before irradiation). A similar conclusion applies to $9 \mathrm{Cr}-1 \mathrm{MoVNb}$ (modified $9 \mathrm{Cr}-1 \mathrm{Mo}$, Grade 91 ), which has one of the lowest $\triangle \mathrm{DBTT}$ values $\left(\approx 50^{\circ} \mathrm{C}\right)$ of the conventional steels considered for fusion applications [7].

One of the interesting aspects in comparing the $9 \mathrm{Cr}-2 \mathrm{WV}$ and $9 \mathrm{Cr}-1 \mathrm{MoVNb}$ steels with the $9 \mathrm{Cr}-2 \mathrm{WVTa}$ steel is that the difference in Charpy properties of these steels before and after irradiation occurs despite there being little difference in the strength of the $9 \mathrm{Cr}$ 2WVTa and the other two steels before and after irradiation. This can be seen in the similar irradiation hardening that occurred for the $9 \mathrm{Cr}-2 \mathrm{WV}$ and $9 \mathrm{Cr}-2 \mathrm{WVT}$ steels as measured by $\Delta \sigma_{y}$ (Table 5).

Transmission electron microscopy examination of the normalized-and-tempered $9 \mathrm{Cr}$ $2 \mathrm{WV}$ and $9 \mathrm{Cr}-2 \mathrm{WVTa}$ revealed only minor differences prior to irradiation [ $\underline{3}, 11]$. Likewise, there was no marked difference in microstructure after irradiation, with similar numbers of dislocation loops formed in both steels during irradiation [11]. Thus, the similarity of strength of the two steels before and after irradiation is not unexpected. However, without any gross differences in the microstructure of the two steels, the only other major difference to account for the difference in Charpy properties is the tantalum in solid solution. Based on the amount of tantalum that appeared to be present in the MC carbides of the $9 \mathrm{Cr}-2 \mathrm{WVTa}$, it was estimated that most of the tantalum remained in solid solution (or was incorporated in the $\mathrm{M}_{23} \mathrm{C}_{6}$ precipitate) [11]. An atom probe analysis of the unirradiated $9 \mathrm{Cr}-2 \mathrm{WVTa}$ steel indicated that $\approx 90 \%$ of the tantalum remained in solution in the normalized-and-tempered condition [12].

Tantalum in solution in the 9Cr-2WVTa can probably account for the smaller prioraustenite grain size in that steel than in the $9 \mathrm{Cr}-2 \mathrm{WV}$; a smaller lath (subgrain) size might also be expected but was not observed. This smaller grain size was originally used to explain the difference between the $9 \mathrm{Cr}-2 \mathrm{WV}$ and $9 \mathrm{Cr}-2 \mathrm{WVT}$ a steels [6]. A smaller grain size can lead to a lower DBTT in the normalized-and-tempered condition. However, this explanation was subsequently questioned because in the normalized-and-tempered condition, the two steels had similar yield stresses, and they also had a similar yield stress as the $9 \mathrm{Cr}-1 \mathrm{MoVNb}$, which had the smallest grain size of the three steels [7]. After $\approx 20$ $\mathrm{dpa}$, the $\triangle \mathrm{DBTT}$ of the $9 \mathrm{Cr}-2 \mathrm{WV}$ and $9 \mathrm{Cr}-1 \mathrm{MoVNb}$ were similar, but above the value for the $9 \mathrm{Cr}-2 \mathrm{WVTa}$ [8]. This occurred even though there were differences in the microstructural changes that occurred in the $9 \mathrm{Cr}-2 \mathrm{WV}$ and $9 \mathrm{Cr}-1 \mathrm{MoVNV}$ during irradiation, while the microstructural changes in the 9Cr-2WV and 9Cr-2WVTa were similar [11]. 
These observations lead to the conclusion that microstructure (grain size, precipitate type, etc.) does not provide the sole explanation for the observations on mechanical property changes. It appears that tantalum in solution must cause a higher fracture stress for $9 \mathrm{Cr}-2 \mathrm{WVTa}$ than $9 \mathrm{Cr}-2 \mathrm{WV}$, and the combination of tungsten and tantalum in the $9 \mathrm{Cr}-$ 2 WVTa leads to a higher fracture stress than produced by molybdenum and niobium in $9 \mathrm{Cr}-1 \mathrm{MoVNb}$.

The observation that the $\triangle \mathrm{DBTT}$ of the $9 \mathrm{Cr}-2 \mathrm{WVT}$ a appeared to increase slightly with fluence appears to in agreement with such an explanation. This increase would follow if tantalum is being removed from solution during irradiation and being incorporated in the existing or new precipitates. If this were the case, the $\triangle \mathrm{DBTT}$ of the $9 \mathrm{Cr}-2 \mathrm{WVTa}$ would be expected to increase with fluence as tantalum is removed from solution. Eventually, it might be expected to approach the $\triangle \mathrm{DBTT}$ for the $9 \mathrm{Cr}-2 \mathrm{WV}$. Even if that were to happen, however, the $9 \mathrm{Cr}-2 \mathrm{WVT}$ a should still have the lowest DBTT after irradiation because of the lower DBTT before irradiation.

\section{SUMMARY AND CONCLUSIONS}

Tensile and Charpy impact properties of eight reduced-activation $\mathrm{Cr}-\mathrm{W}$ ferritic steels have been determined after irradiation in FFTF at $365^{\circ} \mathrm{C}$. Tensile specimens were irradiated to 6-8, 15-17, and 26-29 dpa and the Charpy specimens to $\approx 6-8,15-17,20$ 24 , and 26-29 dpa (results for all but the tensile irradiations to 15-17 and 26-29 dpa and the Charpy irradiations to $26-29$ dpa were presented previously). Chromium concentrations in the eight steels ranged from 2.25 to $12 \mathrm{wt} \%$ (all steels contained $0.1 \% \mathrm{C}$ ). The $2.25 \mathrm{Cr}$ steels contained variations of tungsten and vanadium $(21 / 4 \mathrm{CrV}, 21 / 4 \mathrm{Cr}-1 \mathrm{WV}$, $21 / 4 \mathrm{Cr}-2 \mathrm{~W}$ ) and steels with $2.25,5,9$, and $12 \% \mathrm{Cr}$ contained a combination of $2 \% \mathrm{~W}$ and $0.25 \% \mathrm{~V}(2 \mathrm{1} / 4 \mathrm{Cr}-2 \mathrm{WV}, 5 \mathrm{Cr}-2 \mathrm{WV}, 9 \mathrm{Cr}-2 \mathrm{WV}$, and $12 \mathrm{Cr}-2 \mathrm{WV})$. A $9 \mathrm{Cr}$ steel with $2 \% \mathrm{~W}, 0.25 \% \mathrm{~V}$, and $0.07 \% \mathrm{Ta}(9 \mathrm{Cr}-2 \mathrm{WVTa}$ ) was also irradiated. The microstructures of the $21 / 4 \mathrm{Cr}$ steels were bainite with various amounts of polygonal ferrite, while the two $9 \mathrm{Cr}$ steels and the $5 \mathrm{Cr}$ steel were $100 \%$ martensite. The $12 \mathrm{Cr}-2 \mathrm{WV}$ steel was martensite with $\approx 25 \% \delta$-ferrite. The properties of the steels with $100 \%$ martensite were superior to those with the duplex structures of bainite and ferrite or martensite and ferrite.

Irradiation caused an increase in strength during the first irradiation period (6-8 dpa), but there was little further hardening for the subsequent irradiations, indicating that the hardening saturated with fluence. The DBTT increased with irradiation, and USE decreased, but indications were that saturation occurred for most of the steels after the initial 6-8 dpa irradiation. The $21 / 4 \mathrm{Cr}-2 \mathrm{WV}$ steel had the most irradiation resistance of the four $21 / 4 \mathrm{Cr}$ steels, but it was. concluded that this resistance would be improved if it were $100 \%$ bainite (it contained $\approx 25 \%$ polygonal ferrite). The $9 \mathrm{Cr}$ steels were least affected by irradiation, with the $9 \mathrm{Cr}-2 \mathrm{WVTa}$ showing only a $32^{\circ} \mathrm{C}$ increase in DBTT after $\approx 28 \mathrm{dpa}$. This was the only steel that showed a slight increase in the shift with increasing

fluence, with the $32^{\circ} \mathrm{C}$ shift being an increase from shifts of 4,14 , and $21^{\circ} \mathrm{C}$ in the previous irradiations to $\approx 6.4,15.4$, and $22.5 \mathrm{dpa}$, respectively. Despite the slight increase, $32^{\circ} \mathrm{C}$ is one of the lowest shifts in DBTT for this type of steel irradiated to these conditions, and it compares with a $61^{\circ} \mathrm{C}$ shift for the $9 \mathrm{Cr}-2 \mathrm{WV}$, which had the second 
lowest shitt. The advantage for the $9 \mathrm{Cr}-2 \mathrm{WVTa}$ over the $9 \mathrm{Cr}-2 \mathrm{WV}$ is further enhanced by the much lower DBTT of the 9Cr-2WVTa before irradiation. The advantage of the $9 \mathrm{Cr}-2 \mathrm{WVTa}$ was attributed to the tantalum in solution, and the increase in DBTT with irradiation was thought to be caused by a loss of the tantalum from solution.

\section{ACKNOWLEDGMENT}

Research sponsored by the Office of Fusion Energy Sciences, U.S. Department of Energy, under contract DE-AC05-960R22464 with Lockheed Martin Energy Research Corp. Charpy tests were carried out by E. I. Manneschmidt. Tensile tests were conducted by L. T. Gibson and N. H. Rouse. The manuscript was reviewed by Drs. R. K. Nanstad and J. P. Robertson.

\section{REFERENCES}

[1] Klueh, R. L., Ehrlich, K., and Abe, F., "Ferritic/Martensitic Steels: Promises and Problems," Journal of Nuclear Materials, Vol. 191-194, 1992, pp. 116-124.

[2] Conn, R. W. et al., "Panel Report on Low Activation Materials for Fusion Applications, University of California, Los Angeles, PPG-753, March 1983.

[3] Klueh, R. L. and Maziasz, P. J., "Microstructure of Cr-W Steels," Metallurgical Transactions, Vol. 20A, 1989, pp. 373-382.

[4] Klueh, R. L., "Heat Treatment Behavior and Tensile Behavior of Cr-W Steels," Metallurgical Transactions, Vol. 20A, 1989, pp. 463-470.

[5] Klueh, R. L. and Corwin, W. R., "Impact Behavior of Cr-W Steels," Journal of Materials Engineering, Vol. 11, 1989, pp. 169-175.

[] Klueh, R. L., Alexander, D. J., and Maziasz, P. J., "Impact Behavior of ReducedActivation Ferritic Steels Irradiated in the Fast Flux Test Facility,", Journal of Nuclear Materials, Vol. 186, 1992, pp. 185-195.

[7] Klueh, R. L. and Alexander, D. J., "Impact Toughness of Irradiated ReducedActivation Ferritic Steels," Journal of Nuclear Materials, Vol. 212-215, 1994, pp. 736-740. [8] Klueh, R. L. and Alexander, D. J., "Impact Behavior of Reduced-Activation Steels Irradiated to $24 \mathrm{dpa}$, Journal of Nuclear Materials, to be published.

[9] Alexander, D. J., Nanstad, R. K., Corwin, W. R., and Hutton, J. T., "A Semiautomated Computer-Interactive Dynamic Impact Testing System," Applications of Automation Technology to Fatigue and Fracture Testing, ASTM STP 1092, Braun, A. A., Ashbaugh, N. E., and Smith, F. M., Eds., American Society for Testing and Materials, Philadelphia, 1990, pp. 83-94.

[10] Klueh, R. L., Maziasz, P. J., and Alexander, D. J., "Heat Treatment Effect on Impact Properties of Reduced-Activation Steels," Journal of Nuclear Materials, Vol. 179-181, 1991, pp. 679-683.

[11] Kai, J. J. and Klueh, R. L. R. L., "Microstructural Analysis of Neutron Irradiated Martensitic Steels," Journal of Nuclear Materials, to be published

[12] Jayaram, R. and Klueh, R. L., to be published. 
[13] Anderko, K., Schafer, L., and Materna-Morris, E., "Effect of $\delta$-Ferrite Phase on the Impact Properties of Martensitic Chromium Steels," Journal of Nuclear Materials, Vol. 179-181, 1991, pp. 492-495.

\section{DISCLAIMER}

This report was prepared as an account of work sponsored by an agency of the United States Government. Neither the United States Government nor any agency thereof, nor any of their employees, makes any warranty, express or implied, or assumes any legal liability or responsibility for the accuracy, completeness, or usefulness of any information, apparatus, product, or process disclosed, or represents that its use would not infringe privately owned rights. Reference herein to any specific commercial product, process, or service by trade name, trademark, manufacturer, or otherwise does not necessarily constitute or imply its endorsement, recommendation, or favoring by the United States Government or any agency thereof. The views and opinions of authors expressed herein do not necessarily state or reflect those of the United States Government or any agency thereof. 